\title{
Screening of antioxidant property of Eclipta alba
}

\author{
Mittal R ${ }^{1 *}$, Kumar R2, Chahal HS ${ }^{3}$ \\ ${ }^{1}$ University college of Pharmacy, Guru Kashi University, Talwandi Sabo, Bathinda. Punjab, India \\ ${ }^{2}$ Shivalik College of Pharmacy, Nangal, Punjab, India \\ ${ }^{3}$ Govt Polytechnic College for girls, Patiala. Punjab, India
}

\begin{abstract}
The aim of the study was to examine the possible antioxidant activities of the methanolic extracts of medicinal plants, Eclipta alba. We examined for such properties such as nitric oxide radical scavenging assay, DPPH radical scavenging activity. Free radicals are atoms or molecules that have one or more unpaired electrons on its outer orbital, highly reactive, and could damage cell inside human body. Human body produce antioxidant to neutralize free radicals, but human ageing and stress oxidative conditions would increase the formation of free radicals, therefore an exogenous antioxidant are needed. Asteraceae is the largest family among the plant kingdom, therefore it has a great potential as source of exogenous antioxidant. The flavonoid content of the plant extract was estimated by the method of (Lamaison and Carnat, 1990). Briefly $1.0 \mathrm{ml}$ of plant extract was mixed with $1.0 \mathrm{ml}$ of aluminium chloride reagent and resultant colour was read at $430 \mathrm{~nm}$. The flavonoid content of the extract was expressed as mg quercetin equivalent/gm dry wt. of extract. The coarsely powdered plant materials of Eclipta alba (2000 g) were extracted separately to exhaustion in Soxhlet apparatus for 72 hours by using methanol solvent The crude extract was filtered using $125 \mathrm{~mm}$ Whatman ${ }^{\circledR}$ qualitative filter paper under sterile condition. A methanol solution of the sample at various concentrations was added to $0.5 \mathrm{ml}$ of $0.1 \mathrm{mM}$ methanolic solution of DPPH and allowed to stand for 30 min at $25^{\circ} \mathrm{C}$ in darkness. The absorbance of the sample was measured at $517 \mathrm{~nm}$. A $0.1 \mathrm{mM}$ solution of DPPH in methanol was used as control, whereas ascorbic acid was used as reference standard. The mixture was incubated at $25^{\circ} \mathrm{C}$ for $30 \mathrm{~min}$. After $30 \mathrm{~min}, 1 \mathrm{ml}$ of the incubated solution was withdrawn and mixed with $1 \mathrm{ml}$ of Griess reagent (1\% sulphanilamide, $2 \%$ phosphoric acid and $0.1 \%$ naphthyl ethylenediamine dihydrochloride). The absorbance of the pink chromophore formed during the diazotization of the nitrite with sulphanilamide and the subsequent coupling with naphthyl ethylenediamine dihydrochloride was measured at $546 \mathrm{~nm}$. The percentage of inhibition of the extract shown $39 \%$ in $25 \mu \mathrm{g}$ and in $100 \mu \mathrm{g}$ it was 73 percent.
\end{abstract}

Keywords: Eclipta alba, DPPH, NO, Antioxidant

Article Info: Received 08 Oct 2018; Review Completed 22 Nov 2018; $\quad$ Accepted 24 Nov 2018; Available online 15 Dec 2018

Cite this article as:

Mittal R, Kumar R, Chahal HS, Screening of antioxidant property of Eclipta alba, Journal of Drug Delivery and Therapeutics. 2018; 8(6-s):14-17 DOI: http://dx.doi.org/10.22270/jddt.v8i6-s.2070

*Address for Correspondence:

Mr. Rohit Mittal, University College of Pharmacy, Guru Kashi University, Talwandi sabo, Bathinda, Punjab, India

\section{INTRODUCTION}

Medicinal plant parts are commonly rich in phenolic compounds, such as Flavanoids, phenolic acids, stilbenes, tannins, coumarins, lignans and lignins. These compounds have multiple biological effects including antioxidant activity 1 . Oxygen consumption inherent in cell growth leads to the generation of a series of reactive oxygen species (ROS) ${ }^{2}$. They are continuously produced by the body's normal use of oxygen such as respiration and some cell-mediated immune functions. ROS include free radicals such as superoxide anion radicals $\left(02^{\bullet-}\right)$, hydroxyl radicals $\left(\mathrm{OH}^{\circ}\right)$ and non-free radical species such as hydrogen peroxide $\left(\mathrm{H}_{2} \mathrm{O}_{2}\right)$ and singlet oxygen $\left({ }^{1} \mathrm{O}_{2}\right){ }^{3}$. They accelerate the ageing as well as cause tissue injury and they are continuously formed as a by - product of metabolisms in aerobic organisms and are also produced on exposure to tobacco smoke, ozone, radiations, organic solvents and other environmental pollutants ${ }^{4}$. Eclipta alba (L.) Hassk (synonym Eclipta prostrata) is an annual herbaceous plant, erect or prostrate, belonging to the Asteraceae family. It is also known as Bhringaraj in Ayurveda. There are four main varieties of the herb Eclipta alba based on the colour of their blossom, that is, red, yellow, white, and blue. The white and yellow ones assume an essential part in traditional medicine, but it is the white species (Eclipta $a l b a$ ) that is most commonly harvested for its therapeutic advantages as it grows wildly in moist places, as a weed, and it can be easily propagated. The extracts from the leaves and flowers of this medicinal herb can be applied in numerous ways, both topically and internally, to soothe many ailments 5. Eclipta alba is a plant used in folk and traditional medicine for cirrohosis and infectious diseases. It is believed to prevent aging and rejuvenate hair, teeth, bone, memory, sight, and hearing. Eclipta alba been reviewed for its pharmacological and insecticidal activities and phytochemical constituents, antioxidant, 
antihepatotoxic, anti-hyperlipedemic, anticancer immunomodulatory, analgesic, anti-inflammatory and antidiabetic activities 6 . Moreover, free radical and relative oxygen species are caused by oxidation of biomolecule such as DNA, proteins, carbohydrates, and lipids. This may lead to cell death, cellular compound destruction, DNA breaks, mutagenesis, protein inactivation and membrane disruption ${ }^{7}$. An antioxidant is any substance that delays, prevents or removes oxidative damage to a target molecule. The human body complex antioxidant defense system consists of the dietary intake of antioxidants, as well as the endogenous production of antioxidative compounds, such as glutathione, etc. Eclipta alba is also given to children in case of urinary tract infection. In present study the methanolic extracts of Eclipta alba subjected to analyzed for their antioxidant activity.

\section{MATERIALS AND METHODS}

\section{Plant Material.}

Eclipta alba was collected and the sample was authenticated by Dr. G S Chatha, Shivalik College Pharmacy, Department of Botany, Nangal, India.

\section{Flavonoid Content}

The flavonoid content of the plant extract was estimated by the method of (Lamaison and Carnat, 1990). Briefly $1.0 \mathrm{ml}$ of plant extract was mixed with $1.0 \mathrm{ml}$ of aluminium chloride reagent and resultant colour was read at $430 \mathrm{~nm}$. The flavonoid content of the extract was expressed as $\mathrm{mg}$ quercetin equivalent/gm dry wt. of extract 8 .

\section{Preparation of Eclipta alba Extract}

The fresh whole plant of Eclipta alba was washed with distilled water separately to removed unwanted foreign materials like soil and dusts. After, washed plant material was dried under shade at room temperature without direct exposure of sunrays. It was then coarsely grounded by using mechanical device. The powdered plant material was passed through sieve no 40 and stored in an airtight container for further use. The coarsely powdered plant materials of Eclipta alba (2000 g) were extracted separately to exhaustion in Soxhlet apparatus for 72 hours by using methanol solvent The crude extract was filtered using $125 \mathrm{~mm}$ Whatman ${ }^{\circledR}$ qualitative filter paper under sterile condition. This process was repeated 5 times and then the solvent (alcoholic extract of Eclipta alba), thus collected, was evaporated to dryness under reduced pressure using a rotary evaporator below $50^{\circ} \mathrm{C}$. Residues were further subjected to dryness by incubating them for 8 days at $37^{\circ} \mathrm{C}$ and extract was kept at $4^{\circ} \mathrm{C}$ until use. The yield of the extract was $12.5 \%(\mathrm{w} / \mathrm{w})$.

\section{Preparation of sample extract}

One gram of plant extract was dissolved in $10 \mathrm{ml}$ of respective solvent to make a stock solution of $100 \mathrm{mg} / \mathrm{ml}$. Extracts were further diluted as per requirement in different experiments.

\section{Antioxidant activity determination}

The antioxidant activity of the methanolic extracts of Eclipta alba was determined using DPPH assay and the scavenging activities of nitric oxides. Total phenolic and flavonoid content, the chemicals responsible for the antioxidant activity of these extracts were determined quantitively.

\section{DPPH Radical Scavenging Activity}

The antioxidant activity of the flavonoids was determined in terms of hydrogen donating or radical scavenging ability of antioxidants, using the stable radical 1,1-diphenyl-2picrylhydrazyl (DPPH), according to method of Dnyaneshwar M. Nagmoti, et al. A methanol solution of the sample at various concentrations was added to $0.5 \mathrm{ml}$ of $0.1 \mathrm{mM}$ methanolic solution of DPPH and allowed to stand for $30 \mathrm{~min}$ at $25^{\circ} \mathrm{C}$ in darkness. The absorbance of the sample was measured at $517 \mathrm{~nm}$. A $0.1 \mathrm{mM}$ solution of DPPH in methanol was used as control, whereas ascorbic acid was used as reference standard. All tests were performed in triplicate. Radical scavenging activity was expressed as the inhibition percentage of free radical by the sample and was calculated using the formula

$\%$ inhibition $=\left[\left(\operatorname{Abs}(\right.\right.$ control $\left.)-\mathrm{Abs}_{(\text {sample })}\right] /\left[\mathrm{Abs}_{(\text {control })}\right] \times 100$

Where, Abs control is absorbance of the DPPH+methanol (reacting mixture without the test sample) and Abs sample is absorbance of reacting mixture with the test sample ${ }^{9}$.

\section{Nitric oxide (NO) radical scavenging activity}

Nitric oxide scavenging activity flavonoids was determined in terms of NO generated from decomposition of sodium nitroprusside in aqueous solution at physiological $\mathrm{pH}$ interacts with oxygen to produce nitrite ions, which were measured by the Griess reaction. One milliliter of sodium nitroprusside $(10 \mathrm{mM})$ in phosphate-buffered saline $(\mathrm{pH}$ 7.4) was mixed with $1 \mathrm{ml}$ of test sample solution at various concentrations dissolved in methanol and a control without a test compound, but with an equivalent amount of methanol. The mixture was incubated at $25^{\circ} \mathrm{C}$ for $30 \mathrm{~min}$. After $30 \mathrm{~min}, 1 \mathrm{ml}$ of the incubated solution was withdrawn and mixed with $1 \mathrm{ml}$ of Griess reagent $(1 \%$ sulphanilamide, $2 \%$ phosphoric acid and $0.1 \%$ naphthyl ethylenediamine dihydrochloride). The absorbance of the pink chromophore formed during the diazotization of the nitrite with sulphanilamide and the subsequent coupling with naphthyl ethylenediamine dihydrochloride was measured at $546 \mathrm{~nm}$. All the tests were performed in triplicate. Percentage inhibition was calculated using the formula

$\%$ inhibition $=[($ Abs $($ control $)-$ Abs $($ sample $)] /[$ Abs (control) $] \times$ 100

\section{RESULT}

The results representing significant antioxidant activity of Methanolic extract of Eclipta alba plant products. However, there are certain photochemical that are not soluble in water such as condensed tannins, flavones, coumarin etc. As the result shows, aqueous extract doesn't indicate the presence of tannin. Methanol is also a good solvent, due to its high polarity. Methanol was found easier to penetrate the cellular membrane to extract the intracellular ingredients from the plant material. IC50 of DPPH scavenging activities of extracts could be seen in Table 1 , Fig 1 . The results were widely varied, ranging from 20 to $50 \mu \mathrm{g} / \mathrm{ml}$, and IC50 of DPPH ascorbic acid as standard was also taken in same range. The nitric oxide radical scavenging activities of Eclipta alba extracts were shown in the Table 2, Figure 2 and are compared against the nitric oxide radical scavenging activity of ascorbic acid. The percentage of inhibition of the extract shown 39\% in $25 \mu \mathrm{g}$ and in $100 \mu \mathrm{g}$ it was 73 percent. 
Table: 1 Antioxidant activity of Methanolic extract of Eclipta alba against Standard Ascorbic acid

\begin{tabular}{|c|c|c|c|c|}
\hline & & & \multicolumn{2}{|c|}{ Percentage scavenging activity } \\
\hline S.No. & $\begin{array}{c}\text { Concentration } \\
(\mu \mathrm{g} / \mathrm{ml})\end{array}$ & Absorbance & Extract & Ascorbic acid (std.) \\
\hline 1 & 20 & 0.47 & $44 \pm 0.158$ & $50 \pm 1.040$ \\
\hline 2 & 30 & 0.39 & $56 \pm 0.067$ & $61 \pm 0.636$ \\
\hline 3 & 40 & 0.24 & $71 \pm 0.121$ & $78 \pm 1.252$ \\
\hline 4 & 50 & 0.14 & $79 \pm 0.227$ & $84 \pm 1.043$ \\
\hline
\end{tabular}

NO

Table: 2 Antioxidant activity of Methanolic extract of Eclipta alba against Standard Ascorbic acid

\begin{tabular}{|c|c|c|c|c|}
\hline & & & \multicolumn{2}{|c|}{ Percentage scavenging activity } \\
\hline S.No. & Concentration & Absorbance & Extract & Ascorbic acid (std.) \\
\hline 1 & 25 & 0.48 & $39 \pm 1.772$ & $42 \pm 0.237$ \\
\hline 2 & 50 & 0.36 & $52 \pm 0.293$ & $59 \pm 0.270$ \\
\hline 3 & 75 & 0.24 & $66 \pm 0.224$ & $68 \pm 0.103$ \\
\hline 4 & 100 & 0.18 & $73 \pm 0.084$ & $79 \pm 0.220$ \\
\hline
\end{tabular}

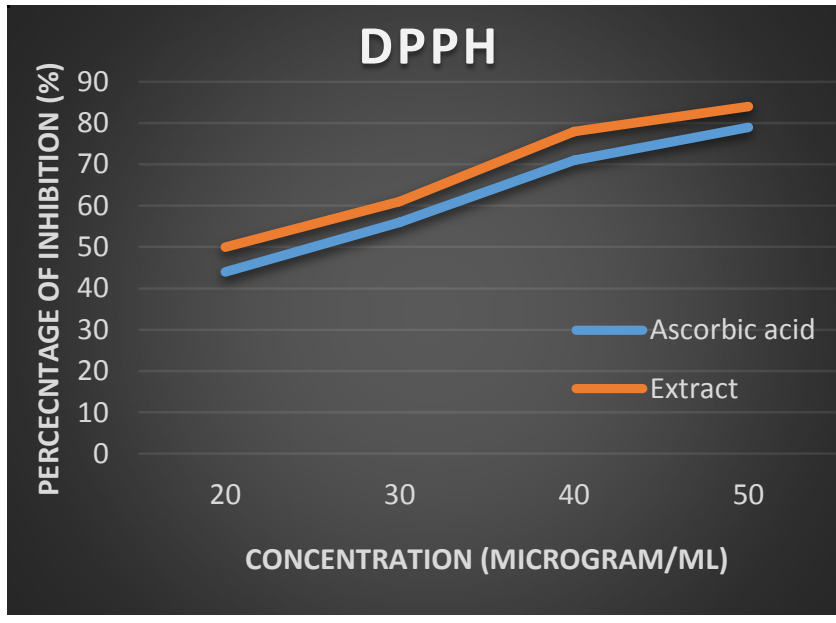

Figure 1; DPPH radical scavenging activity from methanolic extract of Eclipta Alba

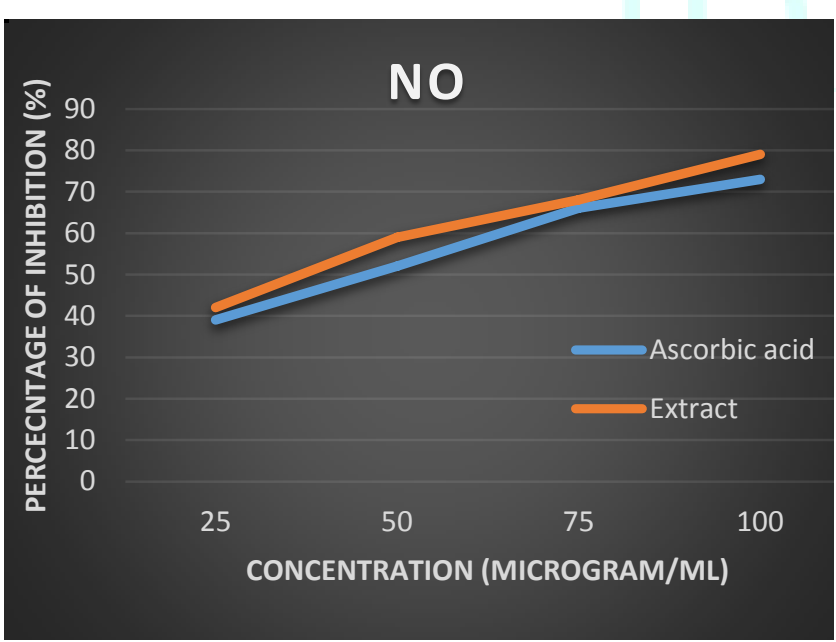

Figure 2: NO radical scavenging activity from methanolic extract of Eclipta Alba

\section{DISCUSSION}

The role of medicinal plants as a source for medicine has been recognized since ancient time. They are helping us to find out totally new chemical classes of therapeutic agents and novel mechanisms of action. On the basis of our results of the present study, it is concluded that the methanol extracts of Eclipta Alba are presented Table-1, and Table 2, have significant antioxidant activity. Nitric oxide (NO) is a potent inhibitor of physiological processes such as neuronal signaling, and inhibition of platelet aggregation, smooth muscle relaxation and regulation of cell mediated toxicity 10 . Nitric oxide (NO) is produced by endothelial cells, macrophages, neurons etc. It acts mainly as signaling molecule in regulation of various physiological processes. Although excess production of this compound is associated with several body disorders. This effect may be due to competition of antioxidant compounds present in extract with oxygen to react with nitric oxide, which ultimately leads to inhibition of generation of nitrite. Effect of different concentrations of methanolic extract on nitric oxide scavenging capacity was determined. The DPPH method applies to the overall antioxidant capacity of the sample. DPPH is a relatively stable free radical and this method determines the ability of methanolic extract of $E$. alba to reduce the DPPH radical to the corresponding hydrazine by reacting with the hydrogen donors in the antioxidant principles. DPPH radicals convert the unpaired electrons to the paired one and the solution loses colour stoichiometrically depending on the number of electrons taken up. The dose dependent inhibition of DPPH by methanolic extract and ascorbic acid ${ }^{11}$.

\section{CONCLUSION}

Methanolic extracts of E. prostrata extracts were investigated for anti-free radical activity by DPPH and NO assay. It is reported that Flavonoids are natural products which have been shown to possess various biological properties related to antioxidant mechanisms. Thus, the antioxidant activity of $E$. alba may be attributed to the presence of this compounds as confirmed by qualitative phytochemical analysis. Hence these results support the view that some traditionally used Indian medicinal plants are promising source of potential antioxidants. Further, study on determination of toxicity of the E. prostrata extracts should be carried on in order to use the plant extracts as antioxidant and dietary supplement. 


\section{REFERENCES}

1. Packer L, Rimbach G, Virgili F, Antioxidant activity and biologic properties of a procyanidin rich extract from pine (Pinus maritima) bark, pycnogenol Free Radic. Biol. Med. 1999, 27:704 724

2. Barros L, Ferreira M, Queiros B, Ferreira IFR, Baptista P, Total phenols, ascorbic acid, $\beta$-carotene and lycopene in Portuguese wild edible mushrooms and their antioxidant activities, Food Chem, 2006; 103:413-419.

3. Gulcin I, Antioxidant and antiradical activities of L-carnitine, Life Sci, 2006; 78:803-811.

4. Singh N, Singh BR, Singh RL, Prakash D, Dhakarey R, Upadhyay G, Singh HB, Oxidative DNA damage protective activity, antioxidant and anti - quorum sensing potentials of Moringa oleifera, Food and Chemical Toxicology, 2009; 47(6):1109-1116.

5. Yadav NK, Arya RK, Dev K, Sharma C, Hossain Z, Meena S, Arya RK, Gayen JR, Datta D, Singh RK, Alcoholic Extract of Eclipta alba Shows In Vitro Antioxidant and Anticancer Activity without Exhibiting Toxicological Effects; Oxidative Medicine and Cellular Longevity; 2017; 9094641:1-18.
6. Jadhav VM, Thorat RM, Kadam VJ, Sathe NS, Eclipta alba (L.) Hassk. - Kesharaja : A Review, J. Pharmacy Res., 2009; 2(8):12361241.

7. Pukumpuang W, Chansakaow S, Tragoolpua Y; Antioxidant Activity, Phenolic Compound Content and Phytochemical Constituents of Eclipta prostrata; Chiang Mai J. Sci. 2014; 41(3):568-576.

8. Patel M, Verma R, Srivastav P; Antioxidant activity of Eclipta alba extract; Journal of Medicinal Plants Studies, 2016; 4(5):92-98.

9. Nagmoti DM, Khatri DK, Juvekar PR, Juvekar AR, Antioxidant activity free radical-scavenging potential of Pithecellobium dulce Benth seed extracts; Free Radicals and Antioxidants, 2012; 2(2):37-43.

10. Geethika B, Gayathri R, Vishnu Priya V, Comparative in-vivo Free Radical Scavenging Activity of Pineapple and Eclipta alba Extracts by NO Assay, Int. J. Pharm. Sci. Rev. Res., 2016; 39(2):6972.

11. Baldi A, Gupta R, Mangal S. Panwar, Antioxidant and antibacterial activity from whole plant of Eclipta alba (l.)-an in vitro model; International Journal of Pharmaceutical \& Biological Archives 2011; 2(2):767-771. 